\title{
Evaluation of antioxidant potential and total phenolic content of exotic fruits grown in Colombia
}

\author{
Nely M. Mejia ${ }^{1}$, Jenny P. Castro ${ }^{1}$, Yanet C. Ocampo ${ }^{1}$, Ruben D. Salas ${ }^{1}$, Carla L. Delporte ${ }^{2}$, Luis A. Franco ${ }^{*}$ \\ ${ }^{1}$ Biological Evaluation of Promising Substances Group, Faculty of Pharmaceutical Sciences, University of Cartagena, Cartagena, Colombia. \\ ${ }^{2}$ Facultad de Medicina, Universidad de Chile, Santiago, Chile.
}

\section{ARTICLE INFO \\ Received on: $14 / 03 / 2020$ \\ Accepted on: 17/07/2020 \\ Available online: 05/09/2020}

\section{Key words:}

Fruits, phenolic compounds, oxidative stress, antioxidant activity.

\begin{abstract}
Disruption of the balance between reactive oxygen species (ROS) production and endogenous antioxidant defenses leads to oxidative stress, which is related to the appearance of chronic noncommunicable diseases (NCDs). The antioxidant compounds present in fruits, including phenolic compounds, suggest that high fruit consumption may contribute to counteracting oxidative stress. The antioxidant potential of ten fruits grown in Colombia was evaluated by quantifying the content of total phenolic compounds, as well as their free radical scavenging capacity [2,2-diphenyl1-picrylhydrazyl (DPPH), 2,2'-azino-bis(3-ethylbenzothiazoline-6-sulfonic acid) diammonium salt (ABTS), peroxyl radicals (ROO), and nitric oxide (NO)], the reduction capacity of ferric reducing antioxidant power (FRAP), and the inhibition of the generation of ROS using the 2',7'-dichlorofluorescein diacetate (DCFH-DA) method in RAW 264.7 mouse macrophages. Regarding phenolic compounds, the extracts of banana passion and sour guava presented the highest content. These extracts also presented the most potent ferric-reducing ability and the best scavenging activity of DPPH, ABTS, NO, and ROO. Moreover, banana passion, yellow pitaya, and golden berry extracts significantly inhibited the production of ROS on LPS-stimulated macrophages. Our results show that banana passion, yellow pitaya, and golden berry are essential sources of molecules with antioxidant activity and their intake could modulate oxidative stress and consequently could help prevent or reduce the incidence of NCDs.
\end{abstract}

\section{INTRODUCTION}

The generation of reactive oxygen species (ROS) by the body's metabolism has a beneficial role in killing infectious agents and regulating cell signaling pathways, as well as genes related to the inflammatory and immune response (Khurana et al., 2013). Nevertheless, the imbalance produced by this intracellular accumulation of ROS induces oxidative stress, which is a cellular state in which DNA, carbohydrates, proteins, and lipids are oxidized, resulting in impaired cellular function, mutations, and cell death. These cellular alterations have been related to the initiation and progression of diseases such as diabetes, cancer, cardiovascular disease, and Alzheimer's disease, among others that are classified as noncommunicable

\footnotetext{
*Corresponding Author
}

Luis A. Franco, Biological Evaluation of Promising Substances Group, Faculty of Pharmaceutical Sciences, University of Cartagena, Cartagena, Colombia.E-mail: Ifrancoo@unicartagena.edu.co diseases (NCDs) (Lee et al., 2015; Liguori et al., 2018). In this sense, substances capable of inhibiting the excessive production of ROS could become an alternative to reduce the incidence of NCDs.

Results obtained in epidemiological studies showed a correlation between the high consumption of fruits and the prevention of NCDs, especially cardiovascular diseases and cancer (Aune et al., 2017; Boeing et al., 2012; Wang et al., 2014). Based on these studies, the World Health Organization has recommended the consumption of five servings of fruits and vegetables daily as per the Strategy for the Prevention and Control of NCDs (Aune et al., 2017). Consistent with this recommendation, the relationship between fruit consumption and health promotion has been evidenced by the increase in the number of bibliographic references. These studies concluded that the positive effect of fruits on health is associated with their content of phytochemicals, mainly phenolic compounds (Côté et al., 2010; Hidalgo and Almajano, 2017; Kalaycıoğlu and Erim, 2017; Skrovankova et al., 2015). These compounds have a recognized antioxidant effect 
and, therefore, have been associated with the prevention of NCDs (Y Aboul-Enein et al., 2013; Zhang et al., 2015).

The demand for fruits in national and international markets has continuously grown, perhaps by the publications that show that low consumption of fruits is among the main factors associated with worldwide mortality. On the contrary, fruit intake is related to a decreased risk of NCDs (Khoo et al., 2011; Slavin and Lloyd, 2012). Colombia is one of the countries that is considered as megadiverse, since it has a great variety of exotic fruits (Contreras-Calderón et al., 2011). Fruits such as yellow pitaya (Hylocereus megalanthus), banana passion (Passiflora cumbalensis), purple passion fruit (Passiflora edulis), golden berry (Physalis peruviana), tamarillo (Solanum betaceum), lulo (Solanum quitoense), soursop (Annona muricata), kalipatti sapota (Manilkara zapota), sapote (Pouteria sapota), and sour guava (Psidium friedrichsthalianum) are commonly consumed in Colombia and are used extensively to treat various diseases in different regions of the world. For example, soursop and purple passion fruit are used to treat cancer, hypertension, inflammation, among other diseases (Daddiouaissa and Amid, 2018; Nanda et al., 2013; Taïwe and Kuete, 2017). Sapote and tamarillo are useful remedies for patients' gastrointestinal problems (Angulo et al., 2012; Ngomle et al., 2020; Stanley et al., 2009). Golden berry is used to treat asthma, rheumatism, cancer, and leukemia (Hassanien, 2011; Wu et al., 2004a). Lulo is used to treat nerve problems and skin diseases (Bussmann et al., 2018). Kalipatti sapota is used in the treatment of pulmonary diseases and also inhibits the growth of breast and colon cancers (Bano and Ahmed, 2017). Yellow pitaya has a mild laxative effect (Fratoni et al., 2019; Sudha et al., 2017). Leaves and flowers of $P$. cumbalensis are widely employed in folk medicine as a poultice for gastrointestinal problems (Jerves-Andrade et al., 2014). However, no reports of the species of $P$. friedrichsthalianum were found in the literature.

Regarding studies of antioxidant activity, in the literature, there are reports of the antioxidant potential of some fruits included in this study that are evaluated individually. For example, the content of total phenolic compounds and the uptake of radicals 2,2-diphenyl-1-picrylhydrazyl (DPPH) and 2,2'-azinobis(3-ethylbenzothiazoline-6-sulfonic acid) diammonium salt (ABTS) have already been reported for all fruits included in this work (Bravo et al., 2016; dos Reis et al., 2018; Flores et al., 2013; Gordillo et al., 2012; Prabhu et al., 2018; Torres Grisales et al., 2017; Vasco et al., 2008; Woo et al., 2013), while for yellow pitaya and sour guava, there are no activity reports for the ferric-reducing antioxidant power (FRAP) or the oxygen radical absorbance capacity-fluorescein (ORAC-FL) (Bravo et al., 2015, 2016; Espin et al., 2016; González et al., 2012; Gordillo et al., 2012; Penaloza et al., 2017; Shafii et al., 2017; Vasco et al., 2008; Woo et al., 2013; Yahia and Barrera, 2009; Yahia et al., 2011; Zapata et al., 2014). Moreover, the scavenging of nitric oxide radical and the inhibition of the generation of intracellular ROS have been reported only for golden berry, kalipatti sapota, soursop, tamarillo, and purple passion fruit (Gomathy et al., 2013; González et al., 2016; Kou et al., 2009; Maruki-Uchida et al., 2013; Orqueda et al., 2020; Rop et al., 2012; Tan et al., 2018; Wu et al., 2004b; Zamudio-Cuevas et al., 2014). Despite this background, it is complicated to determine which would be the most promising fruits as antioxidants, since the fundamental differences are observed in the extraction methods regarding the used methodology and in the expression of the results. Few reports have studied the antioxidant properties of these fruits under the same experimental conditions (Bravo et al., 2016; Contreras-Calderón et al., 2011). Taking into account the high demand for these fruits, their ethnopharmacological use, and antioxidant history, in this work, we evaluated the antioxidant potential of ten exotic fruits grown in Colombia to identify the promising fruits for the treatment or prevention of NCDs by quantifying the content of total phenolic compounds, as well as their free radical scavenging capacity (DPPH, ABTS, ROO, NO). Additionally, the reduction capacity of the extracts was measured with the FRAP assay and the inhibition of the generation of ROS in lipopolysaccharide (LPS)-stimulated RAW 264.7 mouse macrophages was measured using the DCFH-DA method.

\section{MATERIALS AND METHODS}

\section{Reagents}

Gallic acid, Folin-Ciocalteu, sodium nitroprusside dihydrate, sulfanilamide, horseradish peroxidase, guaiacol, catechin, fluorescein, quercetin, 6-hydroxy-2,5,7,8tetramethylchromane-2-carboxylic acid (Trolox), ABTS, DPPH, 2,2'-azobis(2-methylpropionamidine) dihydrochloride (AAPH), 2,4,6-Tris(2-pyridyl)-s-triazine (TPTZ), 5,5-dimethyl-1-pyrroline N-oxide, N-(1-naphthyl)ethylenediamine dihydrochloride, $2^{\prime}, 7^{\prime}$-dichlorofluorescein diacetate (DCFH-DA), pyrogallol red, ferric chloride, ferrous sulfate heptahydrate, magnesium sulfate heptahydrate, potassium persulfate, and lipopolysaccharide (LPS) were obtained from Sigma-Aldrich (St. Louis, MO). Phosphoric acid, potassium chloride, and sodium chloride were obtained from JT Baker (Phillipsburg, NJ). Methanol, ethanol, dimethyl sulfoxide (DMSO), Dulbecco's modified eagle medium (DMEM), and fetal bovine serum (FBS) were obtained from Thermo Fisher Scientific (Pittsburgh, PA). Caffeic acid, aluminum chloride, ascorbic acid, sodium hydroxide, sodium nitrite, D-glucose, calcium chloride, potassium phosphate monobasic, potassium phosphate dibasic, sodium phosphate dibasic, sodium phosphate monobasic, hydrochloric acid, acetic acid, hydrogen peroxide, and 3-(4, 5-Dimethylthiazol-2-yl)-2, 5-diphenyltetrazolium bromide (MTT) were obtained from Merck Millipore (Burlington, MA).

\section{Fruit samples and determination of physicochemical parameters}

Fruits included in this study were obtained from Fusagasugá (Cundinamarca) and Turbana (Bolívar), which involved yellow pitaya (H. megalanthus), banana passion $(P$. cumbalensis), purple passion fruit ( $P$. edulis), golden berry $(P$. peruviana), tamarillo (S. betaceum), lulo ( $S$. quitoense), soursop (A. muricata), kalipatti sapota (M. zapota), sapote (P. sapota), and sour guava ( $P$. friedrichsthalianum). Representative samples of each fruit were used to determine the soluble solids ( ${ }^{\circ}$ Brix), titratable acidity, and $\mathrm{pH}$ values, which were conducted following the guidelines established by the Association of Official Analytical Chemists (Helrich, 1990). The concentration of the solid soluble content ( ${ }^{\circ}$ Brix) was measured using a digital refractometer (Sper Scientific 300034 ) at $25^{\circ} \mathrm{C}$ and the $\mathrm{pH}$ values were determined by a $\mathrm{pH}$ meter (Starter 3100 , OHAUS) at $25^{\circ} \mathrm{C}$. 


\section{Preparation of extracts and determination of total phenolics content}

Fruits were washed under tap water, weighed, homogenized, frozen at $-80^{\circ} \mathrm{C}$, and lyophilized. The dried material was extracted with ethanol $(96 \%)$ at room temperature in stoppered containers for a defined period of time with frequent agitation until exhaustion and the obtained extract was concentrated in a rotary evaporator at controlled temperatures $\left(38^{\circ} \mathrm{C}-40^{\circ} \mathrm{C}\right)$ and reduced pressure. The Folin-Ciocalteu method was used to quantify the total phenolic compounds (Rivera et al., 2018). Phenolic compounds were calculated as $\mathrm{mg}$ gallic acid equivalents $(\mathrm{GAE}) / 100 \mathrm{~g}$ of fresh weight.

\section{Antioxidant activity assays}

$D P P H$ and ABTS free radical assays

Free radical DPPH and ABTS scavenging was determined using the standard methods with some modifications (Castro et al., 2018). For the uptake of the DPPH radical, $75 \mu \mathrm{l}$ of different concentrations of the fruit extracts were mixed with 150 $\boldsymbol{\mu l}$ of a methanolic solution of DPPH $(70 \mu \mathrm{g} / \mathrm{ml})$. The mixture was allowed to incubate for 30 minutes and the absorbance at $517 \mathrm{~nm}$ was measured. While for the ABTS radical, $20 \mu \mathrm{l}$ of the different concentrations of fruit extracts were mixed with $180 \mu \mathrm{l}$ of the ABTS solution. After 30 minutes of incubation, the absorbance was measured at $734 \mathrm{~nm}$ in a Multiskan Go microplate reader (Thermo Scientific, Waltham, MA). A Trolox standard curve was used to determine the equivalent antioxidant capacity and the results were expressed as $\mu$ mol Trolox equivalents/g of fresh weight.

\section{Ferric-reducing antioxidant power assay}

In this work, we used the standard method with some modifications (Castro et al., 2014). The FRAP reagent was prepared by mixing 10 volumes of $300 \mathrm{mM}$ acetate buffer ( $\mathrm{pH}$ 3.6) with 1 volume of $10 \mathrm{mM}$ TPTZ in $\mathrm{HCl}(40 \mathrm{mM})$ and with 1 volume of $20 \mathrm{mM} \mathrm{FeCl} \cdot 6 \mathrm{H}_{2} \mathrm{O}$. Different concentrations of fruit extracts $(10 \mu \mathrm{l})$ were mixed with the FRAP reagent $(290 \mu \mathrm{l})$, incubated independently at $37^{\circ} \mathrm{C}$, and the absorbance was determined at 593 $\mathrm{nm}$ after 60 minutes of the reaction using an EnSpire Multimode microplate reader (PerkinElmer, Waltham, MA). The FRAP value was determined by plotting a standard curve made by the addition of ferrous sulfate to the FRAP reagent. Results were expressed as $\mu \mathrm{mol}$ of $\mathrm{Fe}^{+2} / 100 \mathrm{~g}$ of fresh weight.

\section{Oxygen radical absorbance capacity-fluorescein}

The ability of fruit extracts to trap the peroxyl radical was determined according to the method proposed by $\mathrm{Ou}$ et al. (2001) and validate by Bisby et al. (2008). The peroxyl radicals generated by the thermal decomposition of AAPH reacted with fluorescein to produce a nonfluorescent product over time. Briefly, $20 \boldsymbol{\mu l}$ of different concentrations of fruit extracts were preincubated for 5 minutes with $120 \boldsymbol{\mu l}$ of fluorescein $(100 \mathrm{nM})$ in a 96-well flat-bottom black plate. After which, $60 \mu \mathrm{l}$ of AAPH $(600 \mathrm{mM})$ was added to each well and the fluorescence was recorded using a Fluoroskan Ascent equipment (Thermo Scientific, Waltham, MA) every 56 seconds for 150 minutes at excitation and emission wavelengths of 485 and $538 \mathrm{~nm}$, respectively. The results were expressed as $\mu \mathrm{mol}$ Trolox equivalents/g of fresh weight.

\section{Hydrogen peroxide scavenging activity}

The method described by Doerge et al. (1997), with some modifications, was used to determine the hydrogen peroxide scavenging activity of fruit extracts. Briefly, $900 \boldsymbol{\mu l}$ of HBSS buffer, $100 \mu \mathbf{l}$ of $\mathrm{H}_{2} \mathrm{O}_{2}(10 \mathrm{mM})$, and $10 \mu \mathbf{l}$ of fruit extracts at different concentrations were incubated for 30 minutes. After incubation, $50 \mu \mathbf{l}$ of guaiacol and $10 \mu \mathbf{l}$ of horseradish peroxidase $(0.6 \mu \mathrm{g} / \mathrm{ml})$ were added and incubated again for 20 minutes. The scavenging activity was determined in a Multiskan EX microplate reader (Thermo Scientific, Waltham, MA) at $450 \mathrm{~nm}$. Results were expressed as $\mu \mathrm{mol}$ Trolox equivalents/g of fresh weight.

\section{Scavenging of the nitric oxide radical}

Nitric oxide is generated by solubilizing sodium nitroprusside in an aqueous solution, where it is transformed into nitrite by the oxygen present in the medium. The produced nitrites are easily quantified by the spectrophotometric assay based on the Griess reaction (Rao, 1997). We incubated $990 \mu \mathrm{l}$ of sodium nitroprusside solution $(10 \mathrm{mM})$ in PBS with $10 \boldsymbol{\mu l}$ of different concentrations of fruit extracts for 4 hours at room temperature. After incubation, equal volumes of Griess reagent and the samples were mixed. The nitric oxide concentration was determined by spectrophotometry at $550 \mathrm{~nm}$ in a Multiskan Go microplate reader (Thermo Scientific, Waltham, MA) by comparing to a standard curve of $\mathrm{NaNO}_{2}(1-200$ $\mu \mathrm{M})$. Results were expressed as $\mu \mathrm{mol}$ of results were expressed as $\mu \mathrm{mol}$ of caffeic acid equivalents/g of fresh weight.

\section{Cellular ROS determination by DCFH-DA}

Cell culture

Murine macrophage RAW cell lines (ATCC® TIB-71 ${ }^{\mathrm{TM}}$, Rockville, MD) were maintained in the DMEM supplemented with $10 \%$ heat-inactivated FBS in a humidified $5 \% \mathrm{CO}_{2}$ atmosphere at $37^{\circ} \mathbf{C}$.

\section{Assessment of cell viability}

The toxicity of fruit extracts on RAW 264.7 macrophages was evaluated using the 3-(4, 5-Dimethylthiazol-2-yl)-2, 5-diphenyltetrazolium bromide (MTT) colorimetric method (Scudiero et al., 1988). RAW 264.7 macrophages were seeded in sterile 96-well plates $\left(2 \times 10^{4}\right.$ cells/well $)$ and incubated at $37^{\circ} \mathrm{C}$ for 48 hours, then the medium was removed, and cells were washed with phosphate buffer saline (PBS) and treated for 30 minutes with different concentrations of fruit extracts, after which, they were activated with LPS $(1 \mu \mathrm{g} / \mathrm{ml})$ and incubated again for 24 hours at $37^{\circ} \mathrm{C}$. Following exposure, the cell culture medium was discarded and $100 \mu \mathrm{l}$ of MTT solution $(0.25 \mathrm{mg} / \mathrm{ml})$ was added to each well of the plate. The plates were incubated at $37^{\circ} \mathrm{C}$ for 4 hours in the $\mathrm{CO}_{2}$ incubator. Finally, $100 \mu \mathrm{l}$ of DMSO was added to dissolve the formazan crystals, and the absorbance was measured at $550 \mathrm{~nm}$ by a Multiskan EX microplate reader (Thermo Scientific, Waltham, MA). In each trial, a group of cells not exposed to the extracts was included as the negative control and a group exposed to Triton X-100 (20\%) as control of maximum toxicity. The viability percentages were calculated, considering the negative control group as $100 \%$ viability.

\section{DCFH assay}

The formation of intracellular ROS was determined using the oxidation-sensitive dye DCFH-DA according to the protocol 
described by Park et al. (2017), with some modifications. For that, macrophages RAW $264.7\left(10 \times 10^{4}\right.$ cells/well) were incubated in 96-well sterile black plates. After 24 hours of incubation, the cells were washed twice with sterile PBS to remove nonadherent cells. The remaining cells were incubated for 30 minutes with different concentrations of fruit extracts and activated with LPS $(1 \mu \mathrm{g} /$ $\mathrm{ml})$. After 24 hours of incubation, the cells were washed three times with sterile PBS, stained with DCFH-DA $(20 \mu \mathrm{M})$ in PBS, and incubated for 30 minutes at $37^{\circ} \mathrm{C}$ in the dark. Fluorescence intensity was measured in a 96-well Fluoroskan Ascent plate reader (Thermo Scientific, Waltham, MA) at an excitation wavelength of $485 \mathrm{~nm}$ and an emission wavelength of $538 \mathrm{~nm}$. Quercetin was used as the positive control.

\section{Statistical analysis}

Antioxidant activity results of three independent assays were reported as mean \pm SEM. A one-way analysis of variance was used to analyze the data, followed by Tukey's and Dunnett's comparison tests. $P$-values less than 0.05 were considered significant.

\section{RESULTS AND DISCUSSION}

Fruits, like vegetables, provide nutrients, such as vitamins and minerals, as well as nonnutritive secondary metabolites with biological activity that can contribute to improving people's health and reducing the risk of chronic NCD. Among these metabolites, phenolic compounds stand out, which have several pharmacological properties and are recognized for their potent antioxidant activity (Liu, 2013). In this work, we evaluated the antioxidant potential as well as the content of total phenolic compounds of ten extracts of fruits grown in Colombia using seven different methods. The information of fruits selected for this study and their state of maturation is presented in Tables 1 and 2 .

\section{Quantification of phenolic compounds}

Results of the quantification of phenolic compounds of fruits under study are presented in Table 3. Considering the broad range of variations in the total phenolic compounds, the fruits were classified into three groups: with a high content ( $>80 \mathrm{mg} \mathrm{GAE} / 100$ $\mathrm{g} \mathrm{FW}$ ), a moderate content (80> mg GAE/100 g FW >40), and a low content $(<40 \mathrm{mg}$ GAE/100 g FW). The results show that only banana passion and sour guava presented high contents of phenolic compounds. On the contrary, yellow pitaya, golden berry, purple passion fruit, sapote, kalipatti sapota, tamarillo, and soursop showed moderate content. Lulo had the lowest content of these compounds.

\section{DPPH, ABTS, and FRAP assay}

Table 3 presents the results of the scavenger capacity of DPPH and ABTS free radicals as well as the FRAP of the ten fruit extracts under study. It can be observed that the extracts of banana passion and sour guava presented the best scavenging activity of radicals DPPH and ABTS and the best activity of ferric ion reduction. On the contrary, the extracts of yellow pitaya, golden berry, purple passion fruit, sapote, kalipatti Sapota, tamarillo, soursop, and lulo had a moderate activity. These results are related to the content of phenolic compounds, showing high correlation coefficients in all cases (DPPH: $r=0.978$; ABTS: $r=0.979$; and FRAP: $r=0.981$ ). These results are similar to those reported by other studies, where

Table 1. Information on fruits included in this study.

\begin{tabular}{|c|c|c|c|c|}
\hline Fruits & Part used & Extract yields (\%) & Voucher number & Collection site \\
\hline $\begin{array}{l}\text { Yellow pitaya } \\
\text { Hylocereus megalanthus }\end{array}$ & Pulp and seed & 24.54 & 199083 & \\
\hline $\begin{array}{l}\text { Banana passion } \\
\text { P. cumbalensis }\end{array}$ & Pulp & 9.78 & 199085 & Fusagasugá \\
\hline $\begin{array}{l}\text { Purple passion fruit } \\
\text { P. edulis }\end{array}$ & Pulp & 13.04 & 199081 & $\begin{array}{c}\text { (Cundinamarca) } \\
\left(4^{\circ} 20^{\prime} 14^{\prime \prime} \mathrm{N}, 74^{\circ} 21^{\prime} 52^{\prime \prime} \mathrm{O}\right)\end{array}$ \\
\hline $\begin{array}{l}\text { Golden berry } \\
\text { P. peruviana }\end{array}$ & Whole fruit & 18.08 & 199086 & $\begin{array}{c}\text { Altitude: } 1,800 \text { masl } \\
\text { Precipitation: } 950 \mathrm{~mm} \text { of rain per year }\end{array}$ \\
\hline $\begin{array}{l}\text { Tamarillo } \\
\text { S. betaceum }\end{array}$ & Pulp & 9.10 & 199080 & Climate: $8^{\circ} \mathrm{C}-28^{\circ} \mathrm{C}$ \\
\hline $\begin{array}{l}\text { Lulo } \\
\text { S. quitoense }\end{array}$ & Pulp and seed & 5.46 & 199084 & \\
\hline $\begin{array}{l}\text { Soursop } \\
\text { A. muricata }\end{array}$ & Pulp & 13.12 & 201951 & \\
\hline $\begin{array}{l}\text { Kalipatti sapota } \\
\text { M. zapota }\end{array}$ & Pulp & 32.27 & 201955 & $\begin{array}{c}\text { Turbana (Bolívar) } \\
\left(10^{\circ} 16^{\prime} 35^{\prime \prime} \mathrm{N}, 75^{\circ} 26^{\prime} 19^{\prime \prime} \mathrm{O}\right)\end{array}$ \\
\hline $\begin{array}{l}\text { Sapote } \\
\text { P. sapota }\end{array}$ & Pulp & 26.26 & 201953 & $\begin{array}{l}\text { Altitude: } 138 \text { masl } \\
\text { Precipitation: } 778 \mathrm{~mm} \text { of rain per year } \\
\text { Climate: } 23^{\circ} \mathrm{C}-32^{\circ} \mathrm{C}\end{array}$ \\
\hline $\begin{array}{l}\text { Sour guava } \\
\text { P. friedrichsthalianum }\end{array}$ & Pulp & 12.01 & 201952 & 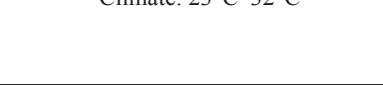 \\
\hline
\end{tabular}

The part of the fruit used to carry out the study and prepare the extracts was selected based on the way people eat the fruit. Yields were calculated as: [(grams of lyophilized pulp/grams of fresh weight) $\times 100]$. 
Table 2. Physicochemical parameters of the fruits.

\begin{tabular}{|c|c|c|c|}
\hline Fruits & Brix & pH & Total acidity $(\mathrm{g} / 100 \mathrm{ml})$ \\
\hline Yellow pitaya & $17.68 \pm 0.27$ & $4.58 \pm 0.01$ & $0.11 \pm 0.01$ \\
\hline Banana passion & $10.62 \pm 0.11$ & $3.41 \pm 0.03$ & $1.23 \pm 0.04$ \\
\hline Purple passion & $15.04 \pm 0.46$ & $3.13 \pm 0.04$ & $2.97 \pm 0.25$ \\
\hline Golden berry & $14.20 \pm 0.06$ & $3.52 \pm 0.006$ & $2.15 \pm 0.01$ \\
\hline Tamarillo & $9.61 \pm 0.14$ & $3.61 \pm 0.004$ & $2.18 \pm 0.03$ \\
\hline Lulo & $9.08 \pm 0.16$ & $3.13 \pm 0.007$ & $3.33 \pm 0.09$ \\
\hline Soursop & $12.57 \pm 0.38$ & $4.06 \pm 0.04$ & $0.62 \pm 0.04$ \\
\hline Kalipatti sapota & $25.37 \pm 0.30$ & $5.25 \pm 0.08$ & $1.80 \pm 0.18$ \\
\hline Sapote & $22.33 \pm 0.37$ & $6.75 \pm 0.05$ & $1.07 \pm 0.02$ \\
\hline Sour Guava & $8.43 \pm 0.20$ & $2.86 \pm 0.02$ & $3.80 \pm 0.09$ \\
\hline
\end{tabular}

The results represent mean $\pm \operatorname{SEM}(n=9)$ from three independent experiments.

Table 3. Quantification of phenolic compounds and antioxidant potential of the extracts by the DPPH, ABTS, and FRAP methods.

\begin{tabular}{lcccc}
\hline Fruits & Phenolic compounds & DPPH & ABTS & FRAP \\
\hline Banana passion & $249.5 \pm 0.064$ & $1959.7 \pm 1.288$ & $4257.3 \pm 0.622$ & $5962.6 \pm 3.241$ \\
Sour guava & $80.9 \pm 0.010$ & $374.5 \pm 0.083$ & $822.3 \pm 0.110$ & $1607.4 \pm 0.220$ \\
Yellow pitaya & $59.1 \pm 0.013$ & $177.1 \pm 0.073$ & $323.8 \pm 0.026$ & $811.2 \pm 0.201$ \\
Golden berry & $53.3 \pm 0.011$ & $78.9 \pm 0.018$ & $228.6 \pm 0.034$ & $419.7 \pm 0.125$ \\
Purple passion fruit & $50.3 \pm 0.006$ & $93.3 \pm 0.030$ & $209.8 \pm 0.027$ & $312.4 \pm 0.149$ \\
Sapote & $49.0 \pm 0.004$ & $136.5 \pm 0.030$ & $310.7 \pm 0.015$ & $549.2 \pm 0.094$ \\
Kalipatti sapota & $44.7 \pm 0.008$ & $73.2 \pm 0.034$ & $193.9 \pm 0.044$ & $412.2 \pm 0.156$ \\
Tamarillo & $41.9 \pm 0.007$ & $72.0 \pm 0.018$ & $197.6 \pm 0.023$ & $427.2 \pm 0.070$ \\
Soursop & $40.4 \pm 0.008$ & $64.3 \pm 0.018$ & $183.8 \pm 0.023$ & $204.1 \pm 0.091$ \\
Lulo & $31.8 \pm 0.006$ & $84.5 \pm 0.036$ & $144.2 \pm 0.008$ & $341.2 \pm 0.147$ \\
\hline
\end{tabular}

Phenolic compounds were calculated as mg gallic acid/100 g of fresh weight. Results of DPPH and ABTS were expressed as micromoles of Trolox equivalents (TEs) per $100 \mathrm{~g}$ of fresh weight ( $\mu \mathrm{mol}$ of TEs $/ 100 \mathrm{~g}$ of FW) and FRAP results as micromoles of Fe $\mathrm{per}^{+2} 100 \mathrm{~g}$ of fresh weight ( $\mu$ mol of $\mathrm{Fe}^{+2} / 100 \mathrm{~g}$ of $\left.\mathrm{FW}\right)$. Results represent mean $\pm \operatorname{SEM}(n=12)$ from three independent experiments.

the free radical scavenging capacity of phenolic compounds is evident; being able to react with highly ROS, donating a hydrogen atom (HA), or transferring a single electron (SE) is all due to the low redox potential that it possesses (Kurek-Górecka et al., 2014). In fact, according to reaction mechanisms, antioxidant activity tests can be classified as a transference assay of an HA or an SE. FRAP and ABTS have been included in the category as the HA assays, while the DPPH assay can be classified in both groups since both reactions can occur, and the antioxidant agent determines the final mechanism (Hidalgo and Almajano, 2017). It should be noted that although the extracts of golden berry, purple passion fruit, and sapote showed a similar content of phenolic compounds, sapote extract presented better free radical scavenging capacity. This may happen because the activity of phenolic compounds also depends on the concentration on the number of hydroxyl groups and the position of the aromatic ring (Kurek-Górecka et al., 2014).

\section{Reactive oxygen species (ROS) and reactive nitrogen species (RNS) scavenging assays}

The excessive production of ROS causes cell toxicity and target organ damage, causing the initiation of NCDs. The results of ROS scavenging activity by those fruit extracts showed that the extracts of yellow pitaya, sour guava, and banana passion exhibited potent peroxyl radical scavenging activity (Table 4). Extracts of sour guava and banana passion significantly decrease the amount of $\mathrm{H}_{2} \mathrm{O}_{2}$, which is an important precursor of hydroxyl radicals among other free radicals.

The NO radical can act directly as an effector molecule or as a second messenger, intervening in numerous signaling pathways (Zhang et al., 2017). When it is produced in excess, it can cause noxious effects, which are related to the capacity of this mediator to react with oxygen, superoxide, and transition metals, generating NOx, peroxynitrite, and heme-complexes, respectively. Peroxynitrite is a powerful, extremely cytotoxic oxidizing agent used by cells of the immune system within its defense mechanisms. However, when produced in excess, it can damage a wide range of molecules in cells, including proteins, DNA, and lipids, which leads to the initiation of a recognized pathophysiological mechanism causing the appearance of chronic NCDs (Pacher et al., 2007). Extracts of sour guava and banana passion presented an important nitric oxide radical scavenging effect (Table 4). It is remarkable that, once again, the fruit extracts with the major activity were those with the highest content of phenolic compounds. 
Table 4. Scavenging effect on reactive oxygen and nitrogen species.

\begin{tabular}{lccc}
\hline Fruits & ORAC & $\mathbf{H}_{2} \mathbf{O}_{2}$ & NO \\
\hline Banana passion & $2409.82 \pm 120.74$ & $38.04 \pm 1.71$ & $70.81 \pm 8.58$ \\
Sour guava & $2602.08 \pm 51.94$ & $36.51 \pm 1.90$ & $168.81 \pm 3.60$ \\
Yellow pitaya & $2999.77 \pm 80.56$ & $2.38 \pm 0.01$ & ulq \\
Golden berry & $350.13 \pm 5.54$ & $4.78 \pm 0.44$ & ulq \\
Purple passion fruit & $471.69 \pm 4.91$ & $13.79 \pm 3.80$ & ulq \\
Sapote & $143.87 \pm 2.65$ & $2.63 \pm 0.15$ & $31.50 \pm 4.22$ \\
Kalipatti sapota & $697.69 \pm 7.82$ & $0.66 \pm 0.14$ & ulq \\
Tamarillo & $169.71 \pm 3.15$ & $4.94 \pm 0.21$ & $18.41 \pm 3.75$ \\
Soursop & $311.24 \pm 3.69$ & $3.84 \pm 0.01$ & ulq \\
Lulo & $133.19 \pm 1.84$ & $1.99 \pm 0.06$ & $37.81 \pm 1.44$ \\
\hline
\end{tabular}

ORAC and $\mathrm{H}_{2} \mathrm{O}_{2}$ scavenging capacities were expressed as micromoles of Trolox equivalents per gram of fresh weight ( $\mu \mathrm{mol}$ of TEs/g of FW). NO scavenging capacity was expressed as micromoles of caffeic acid equivalents per gram of fresh weight ( $\mu$ mol of caffeic acid/g of FW). Results represent mean $\pm \operatorname{SEM}(n=12)$ from three independent experiments. Ulq = Under limit of quantification.

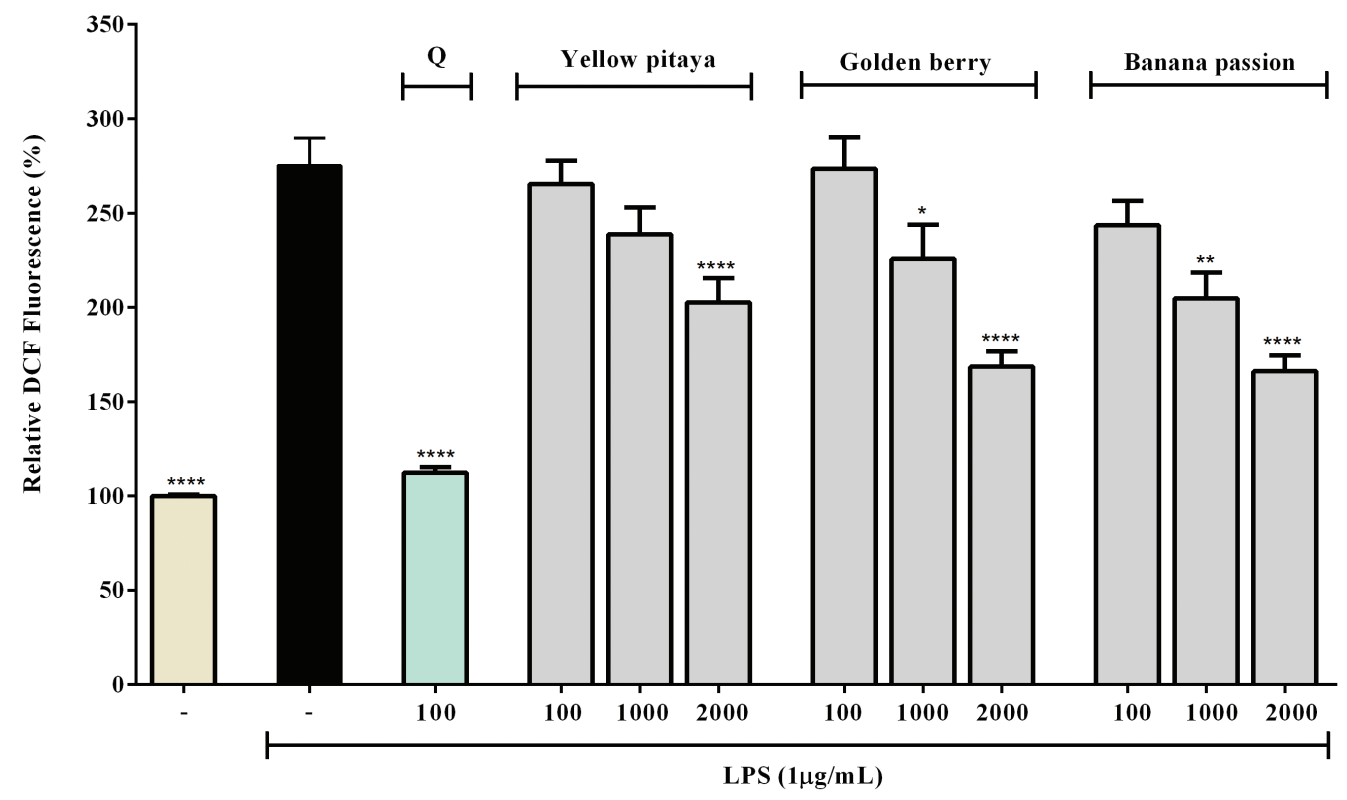

Figure 1. Effect of fruit extracts on the production of intracellular ROS in LPS-stimulated RAW 264.7 macrophages $(1 \mu \mathrm{g} /$ $\mathrm{ml}$ ) for 24 hours. ROS are expressed as fold increase of $2^{\prime}, 7^{\prime}$-dichlorofluorescein fluorescence over LPS-untreated controls. Fruit extracts were evaluated to $100,1,000$, and $2,000 \mu \mathrm{g} / \mathrm{ml}$. Quercetin $(\mathrm{Q})(100 \mu \mathrm{M})$ was employed as the positive control. The results represent mean \pm SEM. $\left({ }^{*} p<0.05 ; * * p<0.01 ;{ }^{* * * *} p<0.0001\right.$ are statistically significant compared to the LPS-treated group).

\section{Production of intracellular ROS}

The DPPH, ABTS, FRAP, and ORAC-FL assays are widely used to evaluate the antioxidant capacity of fruits (Hidalgo and Almajano, 2017). However, in recent years, antioxidant activity assays that include cellular models have been widely accepted since it is considered that the results obtained with them could better predict the antioxidant power of fruits.

In order to deepen the understanding of the antioxidant potential of the ten fruit extracts, their capacity to inhibit the generation of intracellular ROS was measured using DCFH-DA. The extracts of golden berry, banana passion, and yellow pitaya were the most active (Fig. 1). The extracts of sour guava, purple passion fruit, sapote, kalipatti sapota, tamarillo, and lulo showed a low inhibition on the formation of intracellular ROS (data not shown). The extract of soursop fruit was not evaluated because it had a toxic effect on the cells. Note that the extract of golden berry was more active than expected, as it was not the extract with the highest content of phenolic and it did not have the best free radical scavenging effect. The opposite happened with the extract of sour guava, which showed the best free radical scavenging activity and the highest content of phenolic compounds, but it did not exhibit a high capacity to inhibit the production of ROS in the cell assay. In such a way that there is no evidence of a correlation between antioxidant activity at the cellular level and the content of phenolic compounds, contrary to what happens with DPPH, ABTS, and FRAP free radical scavenging assays. It could be because the antioxidant properties of polyphenols depend on the physicochemical environment, which is very complex within a biological matrix, while it is more stable in 
ABTS, DPPH, and FRAP free radical scavenging assays (Scalbert et al., 2005). Furthermore, it is also possible that the antioxidant activity shown by these fruit extracts is due to the presence of other secondary metabolites.

This study provides new information on the antioxidant properties of yellow pitaya, banana passion, lulo, sapote, and sour guava. The results of the scavenging effect on DPPH, ABTS, NO, and peroxyl radicals, as well as the inhibition of the generation of intracellular ROS in macrophages, showed that the total ethanolic extracts obtained from the edible parts of banana passion $(P$. cumbalensis), yellow pitaya ( $H$. megalanthus), and golden berry ( $P$. peruviana) make them the most promising fruits as antioxidants. These results support the ethnopharmacological use of these three fruits, concerning the treatment of various chronic NCDs, in addition to being an essential foundation to continue promoting their consumption.

\section{CONCLUSION}

The fruits like banana passion (P. cumbalensis), yellow pitaya ( $H$. megalanthus), and golden berry ( $P$. peruviana) are a significant source of antioxidant compounds. With the results obtained in this work, we can propose these fruits as functional foods that can be used to enhance health. Nevertheless, these fruit extracts should be evaluated in in vivo models to ensure the bioavailability of the active compounds and should be studied more in-depth regarding their phytochemical characterization to identify the compounds responsible for this activity.

\section{ACKNOWLEDGMENTS}

This research was funded by Colciencias and the University of Cartagena (Grant 110765741311-2014). The authors acknowledge the University of Cartagena (Grants 124-2018 to LF and 02241-2018 to NM) and Colciencias (Grant 647-2014 of the National Doctoral Training Program to JC and Grant 706-2015 of the Program Young Investigators and Innovators to NM). The authors also thank Henry Monroy and the Agrotur (TurbanaBolívar) for their assistance with the fruit collection.

\section{AUTHORS' CONTRIBUTIONS}

RS and LF conceived the study; RS, YO, CD, JC, and LF supervised the study and designed the experiments; NM and JC carried out the experiments; JC and LF wrote the manuscript. All authors read and approved the final manuscript.

\section{CONFLICT OF INTEREST}

The authors state that there is no conflict of interest.

\section{REFERENCES}

Angulo A, Rosero R, Gonzales M. Estudio etnobotánico de las plantas medicinales utilizadas por los habitantes del corregimiento de Genoy, Municipio de Pasto, Colombia. Rev Univ Salud, 2012; 14(2): $168-85$.

Aune D, Giovannucci E, Boffetta P, Fadnes LT, Keum N, Norat T, Greenwood DC, Riboli E, Vatten LJ, Tonstad S. Fruit and vegetable intake and the risk of cardiovascular disease, total cancer and all-cause mortality - a systematic review and dose-response meta-analysis of prospective studies. Int J Epidemiol, 2017; 46(3):1029-56.
Bano M, Ahmed B. Manilkara zapota (L.) P. Royen (Sapodilla): a review. Int J Adv Res Ideas Innov Technol, 2017; 3:1364-71.

Bisby RH, Brooke R, Navaratnam S. Effect of antioxidant oxidation potential in the oxygen radical absorption capacity (ORAC) assay. Food Chem, 2008; 108(3):1002-7.

Boeing H, Bechthold A, Bub A, Ellinger S, Haller D, Kroke A, Leschik-Bonnet E, Müller MJ, Oberritter H, Schulze M. Critical review: vegetables and fruit in the prevention of chronic diseases. Eur J Nutr, 2012; 51(6):637-63.

Bravo K, Alzate F, Osorio E. Fruits of selected wild and cultivated Andean plants as sources of potential compounds with antioxidant and antiaging activity. Ind Crops Prod, 2016; 85:341-52.

Bravo K, Sepulveda-Ortega S, Lara-Guzman O, Navas-Arboleda $\mathrm{AA}$, and Osorio $\mathrm{E}$. Influence of cultivar and ripening time on bioactive compounds and antioxidant properties in Cape gooseberry (Physalis peruviana L.). J Sci Food Agric, 2015; 95(7):1562-9.

Bussmann RW, Zambrana NYP, Romero C, Hart RE. Astonishing diversity - the medicinal plant markets of Bogotá, Colombia. J Ethnobiol Ethnomed, 2018; 14(1):43.

Castro C, Mura F, Valenzuela G, Figueroa C, Salinas R, Zuñiga $\mathrm{MC}$, Torres JL, Fuguet E, Delporte C. Identification of phenolic compounds by HPLC-ESI-MS/MS and antioxidant activity from Chilean propolis. Food Res Int, 2014; 64:873-9.

Castro J, Rivera D, Franco LA. Topical anti-inflammatory activity in TPA-induced mouse ear edema model and in vitro antibacterial of Cordia alba flowers. J Pharm Investig, 2019; 49(3): 331-336.

Contreras-Calderón J, Calderón-Jaimes L, Guerra-Hernández E, García-Villanova B. Antioxidant capacity, phenolic content and vitamin C in pulp, peel and seed from 24 exotic fruits from Colombia. Food Res Int, 2011; 44(7):2047-53.

Côté J, Caillet S, Doyon G, Sylvain J-F, Lacroix M. Bioactive compounds in cranberries and their biological properties. Crit Rev Food Sci Nutr, 2010; 50(7):666-79.

Daddiouaissa D, Amid A. Anticancer activity of acetogenins from Annona muricata fruit. IIUM Med J Malays, 2018; 17(3):103-112.

Doerge DR, Divi RL, Churchwell MI. Identification of the colored guaiacol oxidation product produced by peroxidases. Anal Biochem, 1997; 250(1):10-7.

dos Reis LCR, Facco EMP, Salvador M, Flôres SH, de Oliveira Rios A. Antioxidant potential and physicochemical characterization of yellow, purple and orange passion fruit. J Food Sci Technol, 2018; 55(7):2679-91.

Espin S, Gonzalez-Manzano S, Taco V, Poveda C, Ayuda-Durán B, Gonzalez-Paramas AM, Santos-Buelga C. Phenolic composition and antioxidant capacity of yellow and purple-red Ecuadorian cultivars of tree tomato (Solanum betaceum Cav.). Food Chem, 2016; 194:1073-80.

Flores G, Dastmalchi K, Wu S-B, Whalen K, Dabo AJ, Reynertson KA, Foronjy RF, Jeanine M, Kennelly EJ. Phenolic-rich extract from the Costa Rican guava (Psidium friedrichsthalianum) pulp with antioxidant and anti-inflammatory activity. Potential for COPD therapy. Food Chem, 2013; 141(2):889-95.

Fratoni MMJ, da Silva KRR, Moreira A. NPK application in yellow pitaya seedlings grown on sand and organic compost. Semina, 2019; 40(5 Supl 1):2179-88.

Gomathy K, Baskar R, Kumaresan K. Comparison of antioxidant potential in pulp and peel extracts of Manilkara zapota (L.) P. Royen. Afr J Biotechnol, 2013; 12(31):4936-43.

González E, Fernández A, Sáyago-Ayerdi S, Estrada R, Vallejo L. In Vitro antioxidant capacity of crude extracts and acetogenin fraction of soursop fruit pulp. Pharm Anal Acta, 2016; 7(484):2.

González E, Vaillant F, Pérez AM, Rojas G. In vitro cellmediated antioxidant protection of human erythrocytes by some common tropical fruits. J Nutr Food Sci, 2012; 2:3. 
Gordillo JC, Ortiz D, Larrahondo JE, Mejía MS, Pachon H. Actividad antioxidante en guanábana (Annona muricata 1.): una revisión bibliográfica. Bol Latinoam Caribe Plant Med Aromát, 2012; 11(2):111-26.

Hassanien MFR. Physalis peruviana: a rich source of bioactive phytochemicals for functional foods and pharmaceuticals. Food Rev Int, 2011; 27(3):259-73.

Helrich K. 1990. Official methods of analysis of the AOAC. 15th edition, Methods 932.06, 925.09, 985.29, 923.03. Association of Official Analytical Chemists, Arlington, VA, 1990.

Hidalgo G-I, Almajano M. Red fruits: extraction of antioxidants, phenolic content, and radical scavenging determination: a review. Antioxidants, 2017; 6(1):7.

Jerves-Andrade L, Cuzco N, Tobar V, Ansaloni R, Maes L. Wilches . Medicinal plants used in south Ecuador for gastrointestinal problems: an evaluation of their antibacterial potential. J Med Plants Res, 2014; 8(45):1310-20.

Kalaycıoğlu Z, Erim FB. Total phenolic contents, antioxidant activities, and bioactive ingredients of juices from pomegranate cultivars worldwide. Food Chem, 2017; 221:496-507.

Khoo H-E, Prasad KN, Kong K-W, Jiang Y, Ismail A. Carotenoids and their isomers: color pigments in fruits and vegetables. Molecules, 2011; 16(2):1710-38.

Khurana S, Piche M, Hollingsworth A, Venkataraman K, Tai T. Oxidative stress and cardiovascular health: therapeutic potential of polyphenols. Can J Physiol Pharmacol, 2013; 91(3):198-212.

Kou M-C, Yen J-H, Hong J-T, Wang C-L, Lin C-W, Wu M-J. Cyphomandra betacea Sendt. phenolics protect LDL from oxidation and PC12 cells from oxidative stress. Food Sci Technol, 2009; 42(2):458-63.

Kurek-Górecka A, Rzepecka-Stojko A, Górecki M, Stojko J, Sosada M, Świerczek-Zięba G. Structure and antioxidant activity of polyphenols derived from propolis. Molecules, 2014; 19(1):78-101.

Lee Y-M, Han S-I, Song BC, Yeum K-J. Bioactives in commonly consumed cereal grains: implications for oxidative stress and inflammation. J Med Food, 2015; 18(11):1179-86

Liguori I, Russo G, Curcio F, Bulli G, Aran L, Della-Morte D, Gargiulo G, Testa G, Cacciatore F, Bonaduce D, Abete P. Oxidative stress, aging, and diseases. Clin Interv Aging, 2018; 13:757-72.

Liu RH. Dietary bioactive compounds and their health implications. J Food Sci, 2013; 78(s1):A18-25.

Maruki-Uchida H, Kurita I, Sugiyama K, Sai M, Maeda K, Ito T. The protective effects of piceatannol from passion fruit (Passiflora edulis) seeds in UVB-irradiated keratinocytes. Biol Pharm Bull, 2013; 36(5):845-9.

Nanda Y, Singson N, Rao AN. Ethnomedicinal plants of thadou tribe of Manipur (India)-1. Pleione, 2013; 7(1):138-45.

Ngomle S, Eko R, Kanwat M, Kalita H, Moyon N. Eating from the wild: an insight into the indigenous wild edible plants consumed by the Digaru Mishmi tribe of Arunachal Pradesh. Indian J Tradit Knowl, 2020; 19(2):360-9.

Orqueda ME, Torres S, Zampini IC, Cattaneo F, Di Pardo AF, Valle EM, Jiménez-Aspee F, Schmeda-Hirschmann G, Isla MI. Integral use of argentinean Solanum betaceum red fruits as functional food ingredient to prevent metabolic syndrome: effect of in vitro simulated gastroduodenal digestion. Heliyon, 2020; 6(2):e03387.

Ou B, Hampsch-Woodill M, Prior RL. Development and validation of an improved oxygen radical absorbance capacity assay using fluorescein as the fluorescent probe. J Agric Food Chem, 2001; 49(10):4619-26.

Pacher P, Beckman JS, Liaudet L. Nitric oxide and peroxynitrite in health and disease. Physiol Rev, 2007; 87(1):315-424.

Park J-Y, Kwon Y-W, Lee SC, Park S-D, Lee J-H. Herbal formula SC-E1 suppresses lipopolysaccharide-stimulated inflammatory responses through activation of $\mathrm{Nrf} 2 / \mathrm{HO}-1$ signaling pathway in RAW 264.7 macrophages. BMC Complement Altern Med, 2017; 17(1):374.

Penaloza J, Canas J, Rojano B, Maldonado M. Antioxidant capacity, polyphenol content and antiproliferative activity of yellow, tropical and andean berries extracts obtained from mixtures of blackberry
(Rubus glaucus), passion fruit (Passiflora edulis and Passiflora ligularis), pineapple (Ananas comosus), guava (Psidium guajava L. Radd) and pineapple guava (Acca sellowiana). Curr Top Nutraceutical Res, 2017; 15(3-4):163.

Prabhu DS, Selvam AP, Rajeswari VD. Effective anti-cancer property of Pouteria sapota leaf on breast cancer cell lines. Biochem Biophys Rep, 2018; 15:39-44.

Rao M. Nitric oxide scavenging by curcuminoids. J Pharm Pharmacol, 1997; 49(1):105-7.

Rivera DE, Ocampo YC, Castro JP, Barrios L, Diaz F, Franco LA. A screening of plants used in Colombian traditional medicine revealed the anti-inflammatory potential of physalis angulata calyces. Saudi J Biol Sci, 2019; 26(7):1758-1766.

Rop O, Mlcek J, Jurikova T, Valsikova M. Bioactive content and antioxidant capacity of cape gooseberry fruit. Open Life Sci, 2012; 7(4):672-9.

Scalbert A, Manach C, Morand C, Rémésy C, Jiménez L. Dietary polyphenols and the prevention of diseases. Crit Rev Food Sci Nutr, 2005; 45(4):287-306.

Scudiero DA, Shoemaker RH, Paull KD, Monks A, Tierney S, Nofziger TH, Currens MJ, Seniff D, Boyd MR. Evaluation of a soluble tetrazolium/formazan assay for cell growth and drug sensitivity in culture using human and other tumor cell lines. Cancer Res, 1988; 48(17):4827-33.

Shafii ZA, Basri M, Malek EA, Ismail M. Phytochemical and antioxidant properties of Manilkara zapota (L.) Proen fruit extracts and its formulations for cosmceuetical application. Asian J Plant Sci Res, 2017; 7(3):29-41

Skrovankova S, Sumczynski D, Mlcek J, Jurikova T, Sochor . Bioactive compounds and antioxidant activity in different types of berries. Int J Mol Sci, 2015; 16(10):24673-706.

Slavin JL, Lloyd B. Health benefits of fruits and vegetables. Adv Nutr, 2012; 3(4):506-16.

Stanley R, Dietzgen R, Gidley, M. Proceedings of the tropical fruits in human nutrition and health conference 2008. Held at Couran Cove Island Resort, Gold Coast, Australia,

Sudha K, Baskaran D, Ramasamy D, Siddharth M. Evaluation of functional properties of hylocereus undatus (White dragon fruit). Int J Agric Sci Res, 2017; 7(5):451-6.

Taïwe G, Kuete V. Passiflora edulis. Medicinal spices and vegetables from Africa. Elsevier, Amsterdam, Netherlands, pp 513-26,

Tan BL, Norhaizan ME, Chan LC. Manilkara zapota (L.) P. Royen leaf water wxtract induces apoptosis in human hepatocellular carcinoma (HepG2) cells via ERK1/2/Akt1/JNK1 signaling pathways. Evid Based Complement Alternat Med, 2018; 2018:17.

Torres Grisales Y, Melo Sabogal DV, Sofía Torres-Valenzuela L, Andrea Serna-Jiménez J, SanínVillarreal A. Evaluation of bioactive compounds with functional interest from yellow pitahaya (Selenicereus megalanthus Haw). Rev Fac Nac Agronomía Medellín, 2017; 70(3):8311-8.

Vasco C, Ruales J, Kamal-Eldin A. Total phenolic compounds and antioxidant capacities of major fruits from Ecuador. Food Chem, 2008; 111(4):816-23.

Wang X, Ouyang Y, Liu J, Zhu M, Zhao G, Bao W, Hu FB. Fruit and vegetable consumption and mortality from all causes, cardiovascular disease, and cancer: systematic review and dose-response meta-analysis of prospective cohort studies. BMJ, 2014; 349:g4490.

Woo P, Yim H, Khoo H, Sia C, Ang Y. Effects of extraction conditions on antioxidant properties of sapodilla fruit (Manilkara zapota). Int Food Res J, 2013; 20(5):2065.

Wu S-J, Ng L-T, Chen C-H, Lin D-L, Wang S-S, Lin C-C. Antihepatoma activity of Physalis angulata and P. peruviana extracts and their effects on apoptosis in human Hep G2 cells. Life Sci, 2004a; 74(16):2061-73.

Wu S-J, Ng L-T, Lin D-L, Huang S-N, Wang S-S, Lin C-C. Physalis peruviana extract induces apoptosis in human Hep G2 cells through CD95/CD95L system and the mitochondrial signaling transduction pathway. Cancer Lett, 2004b; 215(2):199-208. 
Y Aboul-Enein H, Berczynski P, Kruk I. Phenolic compounds: the role of redox regulation in neurodegenerative disease and cancer. Mini Rev Med Chem, 2013; 13(3):385-98.

Yahia E, Barrera A. Antioxidant capacity and correlation with phenolic compounds and carotenoids in 40 horticultural commodities. VI Int Postharvest Symp, ; 877.

Yahia EM, Gutiérrez-Orozco F, Arvizu-de Leon, C. Phytochemical and antioxidant characterization of mamey (Pouteria sapota Jacq. HE Moore \& Stearn) fruit. Food Res Int, 2011; 44(7):2175-81.

Zamudio-Cuevas Y, Díaz-Sobac R, Vázquez-Luna A, LandaSolís C, Cruz-Ramos M, Santamaría-Olmedo M, Martínez-Flores K, Fuentes-Gómez A, López-Reyes A. The antioxidant activity of soursop decreases the expression of a member of the NADPH oxidase family. Food Funct, 2014; 5(2):303-9.

Zapata S, Piedrahita AM, Rojano B. Capacidad atrapadora de radicales oxígeno (ORAC) y fenoles totales de frutas y hortalizas de Colombia. Perspectivas en Nutrición Hum, 2014; 16(1):25-36.
Zhang N, Diao Y, Hua R, Wang J, Han S, Li J, Yin Y. Nitric oxide-mediated pathways and its role in the degenerative diseases. Front Biosci, 2017; 22:824-34.

Zhang Y-J, Gan R-Y, Li S, Zhou Y, Li A-N, Xu D-P, Li H-B. Antioxidant phytochemicals for the prevention and treatment of chronic diseases. Molecules, 2015; 20(12):21138-56.

\section{How to cite this article:}

Mejia NM, Castro JP, Ocampo YC, Salas RD, Delporte CL, Franco LA. Evaluation of antioxidant potential and total phenolic content of exotic fruits grown in Colombia. J Appl Pharm Sci, 2020; 10(09):050-058. 